\title{
Jejunal mucosal gamma glutamyl transferase activity in coeliac disease
}

\author{
M. J. FAIRMAN, B. B. SCOTT ${ }^{1}$, C. TOOTHILL, AND M. S. LOSOWSKY \\ From the University Department of Medicine, St. James's Hospital, Leeds
}

SUMMARY In view of data suggesting that deficiency of gamma glutamyl transferase (GGT) may be the primary abnormality in the small-intestinal mucosa of patients with coeliac disease, this enzyme was measured in mucosal biopsies from coeliac patients at different stages of treatment. Activity was only slightly reduced in only one of nine well-treated patients, suggesting that deficiency of this enzyme has no primary role in the aetiology of coeliac disease.

Although gluten has a central role in the pathogenesis of the small-intestinal mucosal lesion in coeliac disease, it is not known how it exerts its toxic effect. The two main suggested mechanisms to explain the toxicity of gluten are (1) an enzyme defect, permitting the accumulation in the mucosa of a toxic product of gluten, and (2) an immunological response to gluten. Recent evidence, such as the response of mucosa in culture to gluten challenge (Falchuk et al., 1974), the similarity of the mucosal lesions to those seen in rejected animal jejunal homografts (Holmes et al., 1971; Ferguson, 1974), and the behaviour of theliolymphocytes in coeliac disease (Ferguson, 1974), all favour a basic immunological mechanism for the mucosal injury. However, the two theories are not mutually exclusive. For example, an enzyme defect might allow the accumulation of a toxic gluten peptide which provokes a damaging immune response. Many enzyme defects have been demonstrated in coeliac mucosa but they are corrected by treatment with a gluten-free diet suggesting that they are secondary to the mucosal damage (Spiro et al., 1964; Samloff et al., 1965). Thus it is clearly important to study mucosa which is normal after treatment with a gluten-free diet.

The enzyme gamma glutamyl transferase (GGTformerly known as gamma glutamyl transpeptidase) is a particularly suitable candidate for the missing enzyme in coeliac disease since it has an apparently unique ability to hydrolyse gamma glutamyl bonds (Cohen et al., 1970) which are found in high con-

${ }^{1}$ This paper forms part of the London University MD Thesis of B.B.S.

Received for publication 19 November 1976 centration in gluten. Furthermore, its intestinal mucosal localisation suggests a role for it in the digestion of substances containing such bonds (Greenberg et al., 1967). Cohen et al. (1970) found that the activity of this enzyme was reduced in mucosa of two coeliac patients studied in remission. The mucosa was said to be normal on the basis of both normal histology and disaccharidase activity. However, the reference range was obtained from only four subjects. Lindstrom (1970), using histochemistry, also found GGT more reduced than other peptidases in three untreated coeliac patients and, furthermore, staining for this enzyme was reduced in three treated coeliac patients. If confirmed, these findings would be the first clear-cut evidence of an enzyme deficiency in the muocsa of treated coeliac patients and would have important implications for understanding the pathogenesis of the disease. The present study was therefore designed to assess mucosal GGT activity in patients with coeliac disease, particularly treated patients in whom the mucosa was normal on the basis of normal histology and disaccharidase activity.

\section{Methods}

\section{PATIENTS}

Three groups of patients with coeliac disease were studied:

(1) an untreated group of five patients whose mucosa showed villous atrophy (subtotal in four, partial in one)-four of these subsequently showed an unequivocal morphological response to a gluten-free diet; (2) a partly treated group of eight patients, all of whom were on a gluten-free diet, in whom jejunal histology was still abnormal, although it had im- 
proved in five; (3) a fully treated group of nine patients who had originally had villous atrophy and who had been on a gluten-free diet for more than one year. In all these nine patients the mucosa was normal by histology and stereomicroscopy.

The reference group consisted of 20 patients who were undergoing investigation for possible smallintestinal disease, but in whom the mucosa was normal by histology and stereomicroscopy. The diagnoses were as follows (numbers in parentheses): irritable colon (10), previous gastric surgery (two), chronic pancreatitis (two), cystic fibrosis (one), chronic active hepatitis (one), dietary deficiency (one), ulcerative colitis (one), perforated colonno cause found (one), weight loss-no cause found (one).

\section{SMALL BOWEL BIOPSIES}

These were obtained with a hydraulic biopsy tube (Quinton Instruments, Seattle, USA) from the proximal jejunum under fluoroscopic control, and stored within 15 minutes of collection at $-20^{\circ} \mathrm{C}$ in $1.5 \mathrm{ml}$ normal saline for between one day and 79 weeks. Two biopsies from each coeliac patient were studied and the mean activity calculated for each patient. Fifty-six biopsies from the 20 control patients were studied and the mean activity for each patient was used to prepare the reference range for each enzyme activity.

\section{ENZYME ASSAYS}

The biopsies were thawed, weighed, and homogenised in $1.5 \mathrm{ml}$ normal saline at room temperature. The sucrase, maltase, and lactase activities were determined by a modification of the method of Dahlqvist (1964). GGT activity was estimated by a modification of the method of Rosalki et al. (1970) using a chromogenic substrate glutamyl-p-nitranilide (Boehringer). Buffered substrate, $0.45 \mathrm{ml}$, (L-gamma glutamyl-p-nitranilide, $6.25 \mathrm{mmol} / \mathrm{l}$, freshly dissolved in a buffer of TRIS, $0.1 \mathrm{~mol} / 1$, containing glycylglycine, $0.05 \mathrm{~mol} / 1$, adjusted to $\mathrm{pH} 9$ at $25^{\circ} \mathrm{C}$ ) was incubated with $200 \mu 1$ of homogenate for 30 minutes at $37^{\circ} \mathrm{C}$. The reaction was terminated by the addition of $2.5 \mathrm{ml} 10 \%$ acetic acid and the optical density measured at $410 \mathrm{~nm}$ against a blank consisting of $0.45 \mathrm{ml}$ substrate and $2.5 \mathrm{ml}$ acetic acid incubated with $200 \mu \mathrm{l}$ of homogenate. Enzyme activity was calculated from the molecular extinction coefficient of p-nitraniline in acetic acid.

The enzyme activities were expressed as IU/g tissue wet weight, since separate studies (Scott et al., 1977) have shown this to be the preferred method of expression. However, in order to compare our reference range with values quoted for healthy volunteers in a previous publication (Greenberg et al., 1967), the control results were also expressed as $\mathrm{IU} / \mathrm{g}$ protein.

\section{PROTEIN ASSAY}

The protein content of the homogenates was estimated by the method of Lowry et al. (1951).

\section{STATISTICAL ANALYSIS}

Mucosal disaccharidase activities are known to be lognormally distributed (McMichael et al., 1966; Berg et al., 1970) and, although the number of our controls was small, it seemed likely that GGT activity is similarly distributed. All enzyme activities were therefore transformed to logarithms for the determination of means, standard deviations (SD), and correlation coefficients. The means and SDs were finally expressed in antilog form.

\section{Results}

\section{GGT}

The range in the 20 control subjects was $0 \cdot 6-2 \cdot 6 \mathrm{IU} / \mathrm{g}$ tissue wet weight (mean $\pm 2 \mathrm{SD}$ ) or $4 \cdot 8-20 \cdot 3 \mathrm{IU} / \mathrm{g}$ protein. The individual results in both the control group and the patients are shown in the Figure. In only one of the fully treated coeliac patients was the value just below the control range. The values in the untreated patients (mean $0.9 \mathrm{IU} / \mathrm{g}$ tissue) tended to be lower than in the controls (mean 1.6 $\mathrm{IU} / \mathrm{g}$ tissue), but none was outside the control range. Although higher values were found in the fully treated patients (mean 1.2 IU/g tissue) than in the untreated, the difference was not statistically significant $(P>0.05)$.

\section{DISACCHARIDASES}

The individual results and the reference ranges are shown in the Table. Apart from a single normal value for maltase activity, all the untreated patients had subnormal activity of all three disaccharidases. Of the nine fully treated patients, eight had normal sucrase activity, eight had normal maltase activity, seven had normal lactase activity, and normal activity of all three enzymes was found in all except three. Intermediate values were found in the partly treated patients.

CORRELATION OF GGT AND DISACCHARIDASES IN COELIAC MUCOSA

There were significant correlations between the individual disaccharidases: maltase and sucrase, $r=0.65, \mathrm{~N}=22, \mathrm{P}<0.001$; sucrase and lactase, $r=0.76, \mathrm{~N}=22, \mathrm{P}<0.001$; maltase and lactase, $r=0.57, \quad \mathbf{N}=22, \quad \mathbf{P}<0.01$. The correlations between GGT and each disaccharidase were poorer: GGT and sucrase, $r=0.42, \mathrm{~N}=22, \mathrm{P}<0.05$; 


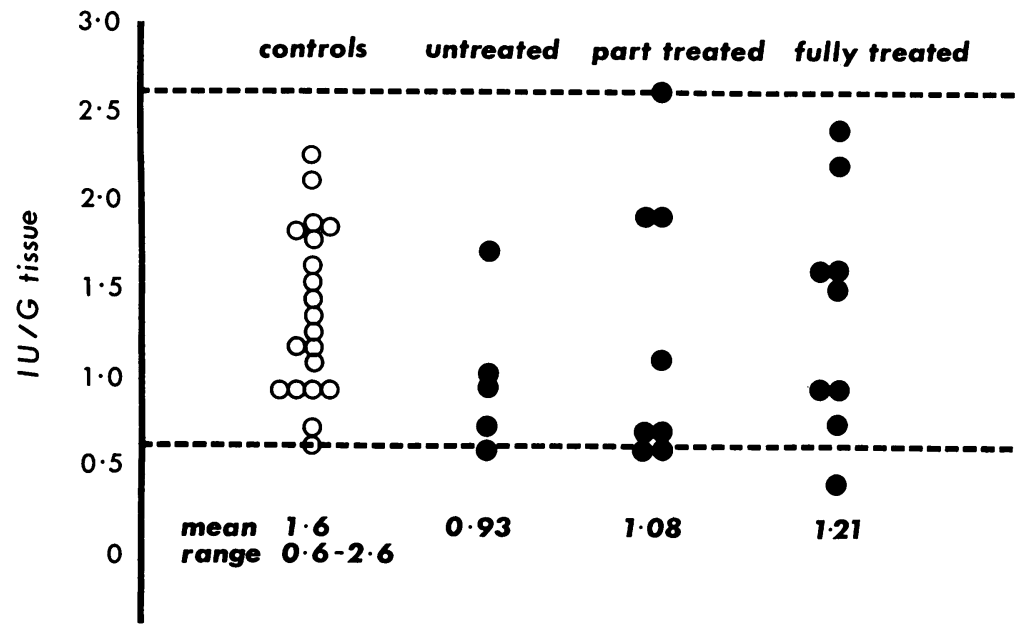

Figure Mucosal GGT activity in controls and in patients with coeliac disease at different stages of treatment.

Table GGT and disaccharidase activities (IU/g tissue) in coeliac patients, untreated $(U)$, partially treated $(P)$, and fully treated with normal jejunal biopsy $(F)$. Individual patients have the same position in the columns of each enzyme

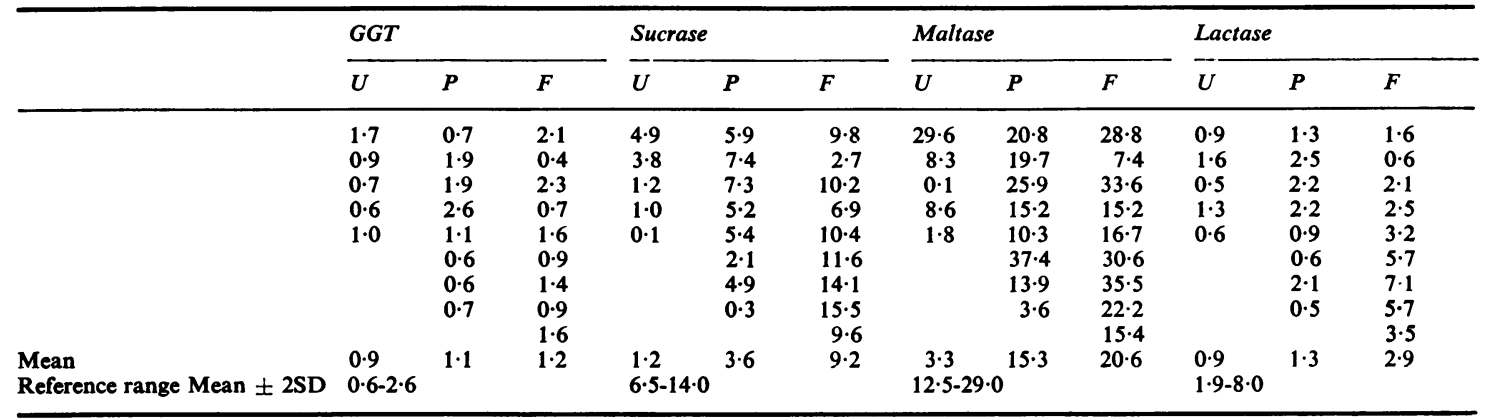

GGT and lactase, $r=0.4, \mathrm{~N}=22, \mathrm{P}=0.05 ; \mathrm{GGT}$ and maltase, $r=0.34, \mathrm{~N}=22, \mathrm{P}>0.05$.

\section{EFFECT OF STORAGE}

To assess the possible effect of storage of biopsies before enzyme assay, the individual values for GGT activity in the controls were plotted against storage time. No correlation was found $(r=0 \cdot 20, \mathrm{P}>0 \cdot 1)$.

\section{Discussion}

The demonstration of normal or near normal GGT activity in all of the fully treated coeliac patients suggests that deficiency of this enzyme has no primary role, at least in the majority of patients, in the causation of coeliac disease. These results differ from those reported by Cohen et al. (1970) who found that two coeliac patients in remission who had normal jejunal histology, had GGT values of $2 \cdot 8$ and $3.1 \mathrm{IU} / \mathrm{g}$ tissue compared with their reference range (obtained from only four subjects) of 5.4 \pm 1.3 (SD) $\mathrm{IU} / \mathrm{g}$ tissue. The differences between these and our own observations may result from the larger number of patients and controls in the present study. The values for our control patients $(0 \cdot 6-2.6 \mathrm{IU} / \mathrm{g}$ tissue, $4 \cdot 8-20 \cdot 3 \mathrm{IU} / \mathrm{g}$ protein) were somewhat lower than those of Cohen et al. (1970), but comparable with the range of 5.3-14.0 IU/g protein obtained from 14 healthy volunteers by Greenberg et al. (1967).

In the present study, all the patients in the fully treated group had completely normal histology and stereomicroscopy at the time of biopsy and all except three had normal activity of all three disaccharidases tested. The effect of storage of biopsy material on GGT activity has been said to be negligible for periods of up to two weeks (Greenberg et al., 1967) and for other peptidases up to several months (Lindberg et al., 1968). Many of our specimens were stored for longer than this, but we found no correlation between 
enzyme activity and duration of storage in our controls and our reference range was obtained from samples stored for similar times.

We were surprised to find that four of our five untreated patients had normal GGT activity despite reduced disaccharidase activity. Although the number of untreated patients was too small to draw conclusions, among all the coeliac patients the correlations between GGT and the individual disaccharidases was poorer than the corelations among the disaccharidases. This might suggest a different localisation of GGT compared with disaccharidases. However, in the normal rat smallintestine both GGT and disaccharidases are localised primarily in the brush border membrane of the villus cells (Curthoys and Shapiro, 1975). The possibility should therefore be considered that GGT in coeliac mucosa may have an abnormal localisation compared with the enzyme in normal subjects.

While the possibility remains that deficiency of an intestinal peptidase is the primary defect in coeliac disease, the present study suggests that GGT is not implicated in most such patients.

\section{References}

Berg, N. O., Dahlqvist, A., Lindberg, T., and Norden, A. (1970). Intestinal depeptidases and disaccharidases in celiac disease in adults. Gastroenterology, 59, 575-582.

Cohen, M. I., McNamara, H., Blumenfeld, D., and Arias, I. M. (1970). The relationship between glutamyl transpeptidase and the syndrome of celiac-sprue. In Coeliac Disease, p. 91. Edited by C. C. Booth and R. H. Dowling. Churchill Livingstone: Edinburgh.

Curthoys, N. P., and Shapiro, R. (1975). $\gamma$-glutamyltranspeptidase in intestinal brush border membranes. FEBS Letters, 58, 230-233.

Dahlqvist, A. (1964). Method for assay of intestinal di- saccharidases. Analytical Biochemistry, 7, 18-25.

Falchuk, Z. M., Gebhard, R. L., and Strober, W. (1974). The pathogenesis of gluten sensitive enteropathy (coeliac sprue): organ culture studies. In Coeliac Disease, pp. 107-117. Edited by W. Th. J. M. Hekkens and A. S. Pena. Stenfert Kroese: Leiden.

Ferguson, A. (1974). Lymphocytes in coeliac disease. In Coeliac Disease, pp. 265-276. Edited by W. Th. J. M. Hekkens and A. S. Pena. Stenfert Kroese: Leiden.

Greenberg, E., Wollaeger, E. E., Fleisher, G. A., and Engstrom, G. W. (1967). Demonstration of $\gamma$-glutamyl transpeptidase activity in human jejunal mucosa. Clinica Chimica Acta, 16, 79-89.

Holmes, J. T., Klein, M. S., Winawer, S. J., and Fortner, J. G. (1971). Morphological studies of rejection in canine jejunal allographs. Gastroenterology, 61, 693-706.

Lindberg, T., Nordén, A., and Josefsson, L. (1968). Intestinal depeptidases. Dipeptidase activities in small intestinal biopsy specimens from a clinical material. Scandinavian Journal of Gastroenterology, 3, 177-182.

Lindstrom, C. (1970). Discussion of paper by M. I. Cohen. In Coeliac Disease, p. 103. Edited by C. C. Booth and R. H. Dowling. Churchill Livingstone: Edinburgh.

Lowry, O. H., Rosebrough, N. J., Farr, A. L., and Randell, R. J. (1951). Protein measurement with the Folin phenol reagent. Journal of Biological Chemistry, 193, 265-275.

McMichael, H. B., Webb, J., and Dawson, A. M. (1966). Jejunal disaccharidases and some observations on the cause of lactase deficiency. British Medical Journal, 2, 1037-1041.

Rosalki, S. B., Rau, D., Lehmann, D., and Prentice, M. (1970). Determination of serum gamma glutamyl transpeptidase activity and its clinical applications. Annals of Clinical Biochemistry, 11, 143-147.

Samloff, I. M., Davis, J. S., and Schenk, E. A. (1965). A clinical and histochemical study of celiac disease before and during a gluten free diet. Gastroenterology, 48, 155-172.

Scott, B. B., Fairman, M. J., Toothill, C., and Losowsky, M. S. (1977). The expression of enzyme activity of biopsy tissue from the small intestine. Digestion. (In press.)

Spiro, H. M., Filipe, M. I., Stewart, J. S., Booth, C. C., and Pearse, A. G. E. (1964). Functional histochemistry of the small bowel mucosa in malabsorptive syndromes. Gut, 5 , 145-154. 